\author{
Anna Misztal \\ Uniwersytet Łódzki \\ e-mail: anna.misztal@uni.lodz.pl \\ ORCID: 0000-0002-7455-5290
}

\title{
BEZPIECZEŃSTWO FINANSOWE A ZRÓWNOWAŻONY ROZWÓJ POLSKICH PRZEDSIĘBIORSTW PRZEMYSLOWYCH
}

\section{FINANCIAL SAFETY AND SUSTAINABLE DEVELOPMENT OF POLISH INDUSTRIAL ENTERPRISES}

DOI: 10.15611/e21.2019.1.05

JEL Classification: L20, O12, Q01

\begin{abstract}
Streszczenie: Podstawowym celem niniejszego artykułu jest wskazanie znaczenia bezpieczeństwa finansowego dla zrównoważonego rozwoju polskich przedsiębiorstw przemysłowych. Początkowe rozważania poświęcono omówieniu najważniejszych zagadnień teoretycznych związanych ze zrównoważonym rozwojem przedsiębiorstw oraz z ich bezpieczeństwem finansowym. Zasadnicza część opracowania przedstawia wyniki badania przeprowadzonego z uwzględnieniem zasobów GUS w latach 2010-2017. W celu oceny zależności między bezpieczeństwem a zrównoważonym rozwojem wyznaczono wskaźniki korelacji liniowej Pearsona oraz przeprowadzono estymację klasyczną metodą najmniejszych kwadratów. Uzyskane wyniki wskazują, że w dwóch z czterech analizowanych sekcji, czyli górnictwie i wydobywaniu oraz w przetwórstwie przemysłowym, odnotowano wysoką istotność statystyczną między badanymi zmiennymi. Nie można zatem jednoznacznie stwierdzić, iż bezpieczeństwo finansowe jest kluczową determinantą zrównoważonego rozwoju polskich przedsiębiorstw przemysłowych.
\end{abstract}

Słowa kluczowe: bezpieczeństwo finansowe, zrównoważony rozwój przedsiębiorstw.

Summary: The main aim of this paper is to indicate the importance of financial security for the sustainable development of Polish industrial enterprises. Initial considerations were devoted to the discussion of basic theoretical issues related to sustainable development of enterprises and their financial security. The main part of the study presents the results of a study. In order to assess the relationship between safety and sustainable development, the Pearson linear correlation coefficients were determined and the estimation was carried out using the Classical Method of the Smallest Squares. The obtained results indicate that in two of the four analyzed sections, in Mining and quarrying and in Industrial processing, high statistical significance was recorded between the variables studied. Therefore, it cannot be unequivocally stated that financial security is a key determinant of the sustainable development of Polish industrial enterprises.

Keywords: financial security, sustainable development of enterprises. 


\section{Wstęp}

Zrównoważony rozwój przedsiębiorstw jest kategorią złożoną, oznaczającą taki rozwój ekonomiczny, który uwzględnia osiąganie celów społecznych i dbałość o zasoby środowiska naturalnego. Podstawowym celem podmiotu gospodarczego wdrażającego w praktyce swojego funkcjonowania koncepcję zrównoważonego rozwoju jest podejmowanie działań mających umożliwić maksymalizację bieżących zysków ekonomicznych przy jednoczesnym uwzględnieniu aspiracji organizacji dotyczących realizacji zysków przyszłych. Kwestiami kluczowymi są tu kompleksowe podejście do zarządzania organizacją, funkcjonowanie z poszanowaniem praw zatrudnionych pracowników oraz racjonalne wykorzystanie zasobów przyrody.

Zrównoważony rozwój przedsiębiorstw uzależniony jest od wielu czynników mających charakter wewnętrzny i zewnętrzny. Poza uwarunkowaniami makroekonomicznymi, w tym poziomem rozwoju społeczno-gospodarczego kraju, regulacjami prawnymi odnośnie do ochrony środowiska naturalnego, poziomem świadomości społecznej czy innowacyjnością gospodarki, niezwykle istotne są uwarunkowania związane z samym przedsiębiorstwem. Wyróżnić tutaj należy m.in. branżę, w jakiej przedsiębiorstwo funkcjonuje, świadomość ekologiczną właścicieli i menedżerów, możliwości finansowe, poziom ekoinnowacyjności. Jednym z aspektów wpływających na zrównoważony rozwój przedsiębiorstw jest bezpieczeństwo finansowe, które jest gwarantem istnienia i rozwoju organizacji w przyszłości.

Podstawowym celem artykułu jest określenie wpływu bezpieczeństwa finansowego na zrównoważony rozwój polskich przedsiębiorstw przemysłowych w latach 2010-2017.

\section{Zrównoważony rozwój przedsiębiorstw i jego determinanty}

Zrównoważony rozwój przedsiębiorstw jest odzwierciedleniem realizacji koncepcji zrównoważonego rozwoju na poziomie mikroekonomicznym. Oznacza on rozwój ekonomiczny odbywający się z poszanowaniem praw pracowników oraz ochrony środowiska naturalnego. Wywołuje on konieczność całościowego podejścia do zarządzania podmiotem gospodarczym i formułowania planów i strategii rozwojowych, u których podstaw leżą ochrona zasobów przyrody oraz dobro zatrudnionych w niej pracowników.

Zrównoważony rozwój jest pojęciem szerokim i niejednoznacznym, a w literaturze przedmiotu funkcjonuje wiele jego ujęć. Pierwsza formalna definicja pojawiła się na Sesji Rady Zarządzającej Programu Narodów Zjednoczonych ds. Srodowiska (UNEP) w 1975 r. Wskazała ona, że: „zrównoważony rozwój to taki przebieg nieuchronnego i pożądanego rozwoju gospodarczego, który nie narusza w sposób istotny i nieodwracalny środowiska życia człowieka, nie doprowadza do degradacji biosfery i godzi prawo przyrody, ekonomii i kultury" [Poskrobko 1998, s. 75]. Najbardziej rozpowszechniona definicja pochodzi z Raportu Brundtland Światowej Ko- 
misji do spraw Środowiska i Rozwoju z 1987 r. Podkreśla ona, że w celu zachowania ogólnoświatowego rozwoju konieczne jest podejmowanie takich działań, które „zaspokajałyby potrzeby obecne, nie pozostawiając przyszłych pokoleń możliwości zaspokajania ich potrzeb" [Nasza wspólna... 1991, s. 67].

Zrównoważony rozwój przedsiębiorstw oznacza podejmowanie działań ukierunkowanych na zrównoważenie celów ekonomicznych z celami społecznymi i środowiskowymi [Trojanowski 2015, s. 244]. Oznacza on „rozwój społeczny i gospodarczy przedsiębiorstw, umożliwiający dzisiejsze realizowanie aspiracji i osiąganie zysków bez naruszania możliwości realizowania aspiracji i osiągania zysków w przyszłości" [Witek-Crabb 2005, s. 564]. Stanowi on szeroko rozumianą ekologizację procesów podstawowych przy jednoczesnym spełnianiu potrzeb obecnych i przyszłych interesariuszy przedsiębiorstwa, w tym właścicieli, pracowników oraz otoczenia organizacji [Grudzewski i in. 2010].

Dominującym podejściem do realizacji koncepcji zrównoważonego rozwoju na poziomie przedsiębiorstwa jest orientacja zintegrowana. Wskazuje ona na spojrzenie na organizację przez pryzmat wskaźników nie tylko ekonomicznych, ale również społecznych i środowiskowych. Zrównoważony rozwój przedsiębiorstwa to „rozwój, który zapewnia efektywne wykorzystanie zasobów, co pozwala na maksymalizację zysku uzyskiwanego przez organizację, rozwój kapitału ludzkiego i wykorzystanie technologii przyjaznych dla środowiska" [Tran Thi Hai Yen i in. 2018, s. 171]. Prowadzi on do wzrostu gospodarczego, poprawy poziomu konkurencyjności, osiągnięcia celów społecznych i środowiskowych, w tym sprostania potrzebom przyszłych pokoleń [Barilenko 2014, s. 25-31; Koryakov 2012, s. 110-114]. Ponadto należy podkreślić, że realizacja koncepcji będzie możliwa, kiedy idee będą realizowane w ramach wzajemnych interakcji między organizacjami, jednostkami, społeczeństwem i państwami [Gray 2010, s. 47-62]. Trwałość i zdolność organizacji do przetrwania uzależniona jest od jej rentowności, wydajności, zyskowności, wyników finansowych, odpowiedniego zarządzania środowiskiem oraz aktywami społecznymi, które powinny być razem traktowane jako kapitał przedsiębiorstwa [Doane, MacGillivray 2001]. Zrównoważony rozwój biznesu może być również traktowany jako „zaspokajanie potrzeb bezpośrednich i pośrednich interesariuszy firmy (...) bez narażania swojej zdolności do realizacji potrzeb przyszłych interesariuszy" [Dyllick, Hockerts 2002, s. 131]. Wśród badaczy przedmiotu istnieją znaczne rozbieżności co do kwestii związanych z jednoczesną realizacją triady celów. Część badaczy przedmiotu wskazuje na konflikt między finansowym i społecznym rozwojem organizacji. Niektórzy uważają, że rozwiązywanie spraw pracowników przyczynia się do poprawy wyników ekonomicznych, inni natomiast, że te dwie kwestie są w całości lub w części rozbieżne [Koszel, Weinert 2013]. Podobnie jest w przypadku relacji na linii kwestie ekonomiczne i środowiskowe. Część badaczy przedmiotu uważa, że efektywne zarządzanie środowiskiem naturalnym prowadzi do wzrostu efektywności produkcji, redukcji kosztów oraz poprawy sytuacji rynkowej i reputacji przedsiębiorstw [Miles, Covin 2000, s. 299-311; Ambec, Lanoie 2008, s. 45-62; Molina-Azorin i in. 2009, 
s. 1080-1100]. Inni natomiast podkreślają, że podejmowanie działań i realizacja inwestycji proekologicznych prowadzą do podwyżki kosztów, a same ekoinwestycje mogą ograniczać możliwości wzrostu i poprawy konkurencyjności, w tym również mogą obniżyć wynik finansowy [Jaffe i in. 1995, s. 132-163; Hull, Rothenberg 2008, s. 781-789]. Również w ramach relacji społeczeństwo-środowisko może pojawiać się konflikt interesów, np. efektywne zarządzanie zasobami środowiska naturalnego może kolidować z potrzebami społecznymi [Dresner 2002].

Wydaje się jednakże, że współczesne organizacje, zarządzane przez świadomych właścicieli, nie mają odwrotu od wdrażania koncepcji zrównoważonego rozwoju. Konieczne jest odpowiednie zaprojektowanie systemów zarządzania, modeli biznesowych oraz systemów pomiaru i raportowania efektów funkcjonowania przedsiębiorstwa [Giovannoni, Fabietti, s. 30]. Zrównoważony rozwój przedsiębiorstw jest wypadkową ekoefektywności, społecznej odpowiedzialności, kultury organizacyjnej, ciągłości podejmowanych działań, podejścia do zarządzania ryzykiem, poziomu i jakości przywództwa. Konieczne jest tu uwzględnienie systemowego podejścia do zarządzania rozwojem, „w ramach którego stosuje się pomiar i monitorowanie osiągnięć, jest jednym z kluczowych elementów procesów podejmowania decyzji. Ponadto ważna jest transparentność i raportowanie osiągnięć, szczególnie w odniesieniu do oddziaływania organizacji i jej produktów na interesariuszy" [Brzozowski 2015, s. 140].

Sukces przedsiębiorstw wdrażających koncepcję zrównoważonego rozwoju uzależniony jest od wielu czynników zewnętrznych i wewnętrznych. Pierwsze odnoszą się do uwarunkowań makroekonomicznych, kwestii regulacji prawnych w zakresie ochrony środowiska naturalnego, wsparcia finansowego dla działalności proekologicznej [Misztal 2018, s. 27-40]. Do czynników wewnętrznych należy zaliczyć m.in. stan zasobów finansowo-majątkowych przedsiębiorstwa, przyjętą strategię marketingową, zasoby technologiczne, dostępność do informacji, plan rozwoju, przedsiębiorczość [Burchell 2008, s. 111-118].

Rozpatrując kwestie związane z sytuacją finansową przedsiębiorstw, stwierdza się, że kluczowe dla przestrzegania zasad związanych z ekologizacją procesów oraz dbania o kwestie społeczne jest bezpieczeństwo finansowe, którego poziom jest jedną z podstawowych determinant długotrwałego spojrzenia na organizację i jej rozwój.

\section{Bezpieczeństwo finansowe i jego ocena}

Bezpieczeństwo finansowe jest jedną z podstawowych determinant rozwoju przedsiębiorstwa. Jest ono kategorią złożoną; do jego oceny wykorzystuje się wskaźniki syntetyczne oraz analityczne. W znacznej mierze bezpieczeństwo finansowe decyduje o poziomie konkurencyjności i możliwości ekspansji podmiotów gospodarczych. Ponadto należy podkreślić, że bezpieczeństwo finansowe przedsiębiorstw jest składową bezpieczeństwa finansowego państwa. Uzasadnieniem dla takiego twierdzenia 
jest fakt, że podmioty gospodarcze tworzą wartość dodaną oraz płacą podatki, które są podstawą rozwoju gospodarczego państwa.

Bezpieczeństwo finansowe jest jedną z kluczowych kwestii i znajduje się na drugim poziomie w hierarchii potrzeb Maslowa (gra rynkowa, bezpieczeństwo finansowej, społeczne zaangażowanie, rozpoznawalność, potrzeba rozwoju) [Medvedyeva, Pohosova 2011; Maslou 2003]. Bezpieczeństwo finansowe przedsiębiorstwa jest różnorodnie definiowane. Może oznaczać zdolność podmiotu gospodarczego do zachowania możliwości spłaty bieżących zobowiązań oraz wysokiego poziomu sprawności podejmowanych działań [Franc-Dąbrowska 2006]. Należy przez nie rozumieć proces stałego ograniczania oraz eliminacji ryzyka pieniężnego ukierunkowanego na zabezpieczenie adekwatności kapitałowej [Raczkowski 2014]. Bezpieczeństwo finansowe może być rozumiane jako „stan, który daje poczucie pewności istnienia i gwarancję jego zachowania oraz szanse na rozwój (...); jego mianem można również określić finansową gwarancję istnienia i rozwoju przedsiębiorstwa, która powstaje w wyniku codziennych wieloletnich starań przedsiębiorstwa o zapewnienie dobrej kondycji finansowej" [Karbownik 2012, s. 66]. Poziom bezpieczeństwa finansowego firmy można „scharakteryzować przez pewien stopień harmonizacji czasu i przestrzeni interesów spółki i jej kontrahentów (klientów, dostawców, konkurentów, inwestorów, rządu i społeczeństwa)" [Delasa i in. 2015, s. 250]. Przez bezpieczeństwo finansowe można rozumieć „ochronę interesów finansowych przedsiębiorstw na wszystkich poziomach stosunków finansowych" [Zahorodniy, Voznyuk 2007]. Bezpieczeństwo finansowe może być analizowane na dwóch poziomach:

- operacyjnym, oznacza wówczas ogół finansowych warunków efektywnej i skutecznej kontynuacji działalności przez podmiot gospodarczy, kluczową rolę odgrywa tu dobry standing finansowy,

- strategicznym, podkreślającym czynniki i wskaźniki mające wpływ na długoterminowy rozwój przedsiębiorstw [Karbownik 2014, s. 18].

W dążeniu do niezależności finansowej przedsiębiorstwa można wyróżnić trzy etapy; są nimi:

- osłona finansowa - zapewniająca kontynuację działalności w krótkim okresie, przedsiębiorstwo posiada środki na pokrycie bieżących zobowiązań,

- bezpieczeństwo finansowe - będące gwarancją istnienia i rozwoju przedsiębiorstwa,

- wolność finansowa - poza wyżej wymienionymi przedsiębiorstwo posiada również możliwości finansowe pozwalające na realizację nawet nieprzewidzianych inwestycji [Karbownik 2012, s. 67].

W ocenie bezpieczeństwa finansowego wykorzystywane są wskaźniki memoriałowe i kasowe. Dane do oceny jego poziomu pochodzą zatem ze wszystkich sprawozdań finansowych, w tym przede wszystkim bilansu, rachunku zysków i strat oraz rachunku przepływów pieniężnych.

Na bezpieczeństwo finansowe „oddziałują, obok płynności finansowej i wypłacalności - odpowiednia rentowność, właściwy podział osiągniętego zysku netto, 
a także przychody netto ze sprzedaży produktów, towarów i materiałów" [Karbownik 2014, s. 24]. W literaturze przedmiotu można spotkać różne podejścia do oceny poziomu bezpieczeństwa finansowego przedsiębiorstw. Istnieje jednakże zgodność, jeżeli chodzi o wykorzystanie w ocenie operacyjnego bezpieczeństwa finansowego takich mierników, jak wskaźniki płynności finansowej, rentowności, wydajności gotówkowej. Strategiczne bezpieczeństwo finansowe z kolei uzależnione jest od wskaźników struktury kapitału oraz wypłacalności. Niektórzy badacze przedmiotu wskazują również na znaczenie sprawności działania, dynamiki i struktury aktywów, struktury kapitału, rezerw, rynkowej wartości dodanej [Duraj 2010, s. 346-349; Bednarski, Waśniewski (red.) 1996, s. 315-316; Sierpińska, Jachna 2004, s. 144-221].

\section{Cel i metodyka badania}

Zrównoważony rozwój przedsiębiorstw stanowi odpowiedź na pogłębiające się procesy globalizacji, przemiany społeczeństwa oraz zmiany klimatu. Pomiar i określenie czynników wpływających na rozwój przedsiębiorstw mają kluczowe znaczenie. Badanie przeprowadzono dla polskich przedsiębiorstw przemysłowych $\mathrm{w}$ latach 2010-2017. Dane zaczerpnięto z zasobów portalu GUS, w tym dokumentów, takich jak: wyniki finansowe przedsiębiorstw niefinansowych, bilansowe wyniki finansowe podmiotów gospodarczych i rachunki ekonomiczne środowiska.

Podstawowym celem badania jest statystyczna ocena wpływu poziomu bezpieczeństwa finansowego na zrównoważony rozwój polskich przedsiębiorstw przemysłowych. W celu weryfikacji tych zamierzeń sformułowano następującą hipotezę badawczą: bezpieczeństwo finansowe ma istotny statystycznie wpływ na poziom zrównoważonego rozwoju polskich przedsiębiorstw przemysłowych w latach 2010-2017. Badanie przeprowadzono w następujących etapach:

- Opracowano wskaźniki syntetyczne zrównoważonego rozwoju przedsiębiorstw i bezpieczeństwa finansowego przedsiębiorstw na podstawie wzoru:

$$
S_{j}=\frac{1}{n} \sum_{i=1}^{n} S_{i j},
$$

gdzie: $S_{j}$ - zagregowany miernik dla $j$-tego roku (wskaźnik znormalizowany), $n$ - liczba wskaźników wykorzystanych w modelu.

- Normalizacji wskaźników dokonano na podstawie wzorów:

- stymulanty:

$$
S_{i j}=\frac{X_{i j}}{\max X_{i j}},
$$

gdzie: $x_{i j}$ - wartość $i$-tego miernika dla $j$-tego roku, max $x_{i j}$ - wartość maksymalna $i$-tego miernika dla $j$-tego roku;

- destymulanty: 


$$
S_{i j}=\frac{\min X_{i j}}{X_{i j}},
$$

gdzie: $\min x_{i j}$ - wartość minimalna $i$-tego miernika dla $j$-tego roku.

Syntetyczny wskaźnik zrównoważonego rozwoju przedsiębiorstw opracowano, bazując na takich wskaźnikach analitycznych, jak:

- stymulanty: liczba zarejestrowanych podmiotów gospodarczych, pracujący ogółem, przeciętne miesięczne wynagrodzenie, przychody netto z całokształtu działalności, wynik finansowy brutto (tys. zł), wartość produkcji (tys. zł), wartość dodana (tys. zł),

- destymulanty: koszty z całokształtu działalności (tys. zł), emisja $\mathrm{CO}_{2}$, emisja podtlenku azotu, metanu, wodorofluorowęglowodorów, dwutlenku siarki, amoniaku, emisja pyłu.

Syntetyczny wskaźnik bezpieczeństwa finansowego przedsiębiorstw opracowano na podstawie takich wskaźników analitycznych, jak:

- stymulanty: wskaźnik rentowności obrotu netto, wskaźnik rentowności aktywów, wskaźnik rentowności aktywów trwałych, wskaźnik rentowności aktywów obrotowych, wskaźnik rentowności kapitału własnego, wskaźnik płynności I stopnia, wskaźnik płynności II stopnia, wskaźnik płynności III stopnia,

- destymulanty: relacja zobowiązań do należności.

Zbadano zależność między analizowanymi wskaźnikami syntetycznymi przy wykorzystaniu wskaźnika korelacji liniowej Pearsona oraz klasycznej metody najmniejszych kwadratów (KMNK).

\section{Wyniki badania}

Badanie przeprowadzono z podziałem na sekcje PKD 2007 w latach 2010-2017 (wartość wskaźnika zrównoważonego rozwoju w 2017 r. jest wynikiem prognozy przeprowadzonej za pomocą metody ekstrapolacji trendu). Analizą objęto sekcje: „Górnictwo i wydobywanie”, „Przetwórstwo przemysłowe”, „Wytwarzanie i zaopatrywanie w energię elektryczną”, „Dostawa wody”. Dane o liczbie przedsiębiorstw przedstawiono w tabeli 1. Podstawową grupą wśród analizowanych podmiotów gospodarczych są przedsiębiorstwa przetwórstwa przemysłowego, które stanowią 94\% całej analizowanej zbiorowości.

Wyznaczone wskaźniki zrównoważonego rozwoju zebrano w tabeli 2. Najwyższą przeciętną wartość wskaźnika odnotowano dla sekcji „Przetwórstwo przemysłowe” $(0,9)$, najniższą zaś w sekcji „Górnictwo i wydobywanie” $(0,84)$. Dodatni trend wystąpił w sekcjach „Przetwórstwo przemysłowe” (współczynnik 0,0127), „Wytwarzanie i zaopatrywanie w energię elektryczną" $(0,0096)$ oraz „Dostawa wody” $(0,0174)$. W sekcji „Górnictwo i wydobywanie” wystąpił trend ujemny $(-0,015)$. 
Tabela 1. Liczba przedsiębiorstw przemysłowych (PKD 2007) w Polsce w latach 2010-2016

\begin{tabular}{|l|r|r|r|r|r|r|r|}
\hline \multicolumn{1}{|c|}{ Wyszczególnienie } & \multicolumn{1}{c|}{2010} & \multicolumn{1}{c|}{2011} & \multicolumn{1}{c|}{2012} & \multicolumn{1}{c|}{2013} & \multicolumn{1}{c|}{2014} & \multicolumn{1}{c|}{2015} & \multicolumn{1}{c|}{2016} \\
\hline Górnictwo i wydobywanie & 1789 & 2013 & 1945 & 1658 & 1840 & 2002 & 2048 \\
\hline Przetwórstwo przemysłowe & 176390 & 179155 & 174754 & 174462 & 180506 & 187247 & 195411 \\
\hline $\begin{array}{l}\text { Wytwarzanie i zaopatrywanie } \\
\text { w energię elektryczną }\end{array}$ & 2068 & 2506 & 2730 & 2552 & 2543 & 3134 & 3652 \\
\hline Dostawa wody & 5765 & 6303 & 6794 & 6691 & 7057 & 7432 & 7361 \\
\hline
\end{tabular}

Źródło: [http://swaid.stat.gov.pl].

Tabela 2. Wskaźniki zrównoważonego rozwoju przedsiębiorstw przemysłowych

\begin{tabular}{|l|c|c|c|c|c|c|c|c|c|c|c|l|}
\hline $\begin{array}{c}\text { Wyszcze- } \\
\text { gólnienie }\end{array}$ & 2010 & 2011 & 2012 & 2013 & 2014 & 2015 & 2016 & 2017 & Średnia & Max. & Min. & Linia trendu \\
\hline $\begin{array}{l}\text { Górnictwo } \\
\text { i wydobywanie }\end{array}$ & 0,85 & 0,89 & 0,88 & 0,85 & 0,85 & 0,77 & 0,80 & 0,78 & 0,84 & 0,89 & 0,77 & $\begin{array}{l}y=-0,015 x+ \\
0,9035\end{array}$ \\
\hline $\begin{array}{l}\text { Przetwórstwo } \\
\text { przemysłowe }\end{array}$ & 0,88 & 0,87 & 0,87 & 0,89 & 0,90 & 0,93 & 0,95 & 0,95 & 0,90 & 0,95 & 0,87 & $\begin{array}{l}y=0,0127 x+ \\
0,8477\end{array}$ \\
\hline $\begin{array}{l}\text { Wytwarzanie } \\
\text { i zaopatrywanie } \\
\text { w energię } \\
\text { elektryczną }\end{array}$ & 0,85 & 0,82 & 0,82 & 0,85 & 0,87 & 0,84 & 0,91 & 0,89 & 0,86 & 0,91 & 0,82 & $\begin{array}{l}y=0,0096 x+ \\
0,8146\end{array}$ \\
\hline \begin{tabular}{l} 
Dostawa wody \\
\hline
\end{tabular} & 0,81 & 0,81 & 0,81 & 0,83 & 0,85 & 0,89 & 0,90 & 0,91 & 0,85 & 0,91 & 0,81 & $\begin{array}{l}y=0,0174 x+ \\
0,7737\end{array}$ \\
\hline
\end{tabular}

Źródło: [http://swaid.stat.gov.pl].

Przeciętna wartość wskaźnika syntetycznego bezpieczeństwa finansowego przedsiębiorstw najwyższa była w sekcji „Przetwórstwo przemysłowe” $(0,89)$, najniższa zaś - w sekcji „Górnictwo i wydobywanie” $(0,38)$ (tabela 3). Dodatni trend wskaźnika odnotowano w sekcjach „Przetwórstwo przemysłowe” $(0,0176)$ oraz „Dostawa wody” $(0,0097)$, ujemny zaś - w sekcjach „Górnictwo i wydobywanie” $(-0,102)$ oraz „Wytwarzanie i zaopatrywanie w energię elektryczną” $(-0,037)$.

Wyniki korelacji linowej Pearsona przedstawiono w tabeli 4. Istotną zależność pomiędzy syntetycznymi wskaźnikami bezpieczeństwa finansowego oraz zrównoważonego rozwoju przedsiębiorstw odnotowano w sekcjach „Górnictwo i wydobywanie” $(0,74)$ oraz „Przetwórstwo przemysłowe” $(0,93)$. W pozostałych sekcjach nie odnotowano istotnej statystycznie zależności. Bardzo niski poziom wskaźnika korelacji wystąpił w sekcji „Wytwarzanie i zaopatrywanie w energię elektryczną” $(0,06)$.

Podobne wyniki otrzymano w przypadku estymacji klasyczną metodą najmniejszych kwadratów; zob. tabela 5. Istotna zależność statystyczna pomiędzy analizowanymi wskaźnikami syntetycznymi występuje w sekcjach „Górnictwo i wydobywanie” oraz „Przetwórstwo przemysłowe”. W przypadku pierwszej sekcji, jeżeli wskaźnik bezpieczeństwa finansowego przedsiębiorstw wzrośnie o 1, to poziom wskaźnika zrównoważonego rozwoju wzrośnie o 0,09 (współczynnik determinacji 55\%). 
Bezpieczeństwo finansowe a zrównoważony rozwój polskich przedsiębiorstw...

Tabela 3. Wskaźniki bezpieczeństwa finansowego przedsiębiorstw przemysłowych

\begin{tabular}{|l|l|l|l|l|l|l|l|l|l|l|l|l|}
\hline \multicolumn{1}{|c|}{$\begin{array}{c}\text { Wyszcze- } \\
\text { gólnienie }\end{array}$} & 2010 & 2011 & 2012 & 2013 & 2014 & 2015 & 2016 & 2017 & Średnia & Max. & Min. & Linia trendu \\
\hline $\begin{array}{l}\text { Górnictwo } \\
\text { i wydobywanie }\end{array}$ & 0,66 & 1,00 & 0,51 & 0,35 & 0,18 & $-0,16$ & 0,04 & 0,44 & 0,38 & 1,00 & $-0,16$ & $\begin{array}{l}y=-0,102 x+ \\
0,8357\end{array}$ \\
\hline $\begin{array}{l}\text { Przetwórstwo } \\
\text { przemysłowe }\end{array}$ & 0,87 & 0,84 & 0,85 & 0,88 & 0,85 & 0,93 & 0,99 & 0,95 & 0,89 & 0,99 & 0,84 & $\begin{array}{l}y=0,0176 x+ \\
0,814\end{array}$ \\
\hline $\begin{array}{l}\text { Wytwarzanie } \\
\text { z zaopatrywanie } \\
\text { w energię } \\
\text { elektryczną }\end{array}$ & 0,94 & 0,91 & 0,77 & 0,84 & 0,97 & 0,32 & 0,69 & 0,82 & 0,78 & 0,97 & 0,32 & $\begin{array}{l}y=-0,037 x+ \\
0,9505\end{array}$ \\
\hline \begin{tabular}{l} 
Dostawa wody \\
\hline
\end{tabular} & 0,86 & 0,77 & 0,77 & 0,96 & 0,79 & 0,88 & 0,91 & 0,85 & 0,85 & 0,96 & 0,77 & $\begin{array}{l}y=0,0097 x+ \\
0,8073\end{array}$ \\
\hline
\end{tabular}

Źródło: [https://bdl.stat.gov.pl/BDL/start].

Tabela 4. Korelacje pomiędzy wskaźnikami syntetycznymi bezpieczeństwa finansowego a zrównoważonego rozwoju przedsiębiorstw (oznaczone wsp. korelacji są istotne z $p<, 05$ )

\begin{tabular}{|l|c|}
\hline Górnictwo i wydobywanie & 0,74 \\
\hline Przetwórstwo przemysłowe & 0,93 \\
\hline Wytwarzanie i zaopatrywanie w energię elektryczną & 0,06 \\
\hline Dostawa wody & 0,41 \\
\hline
\end{tabular}

Źródło: opracowanie własne na podstawie [https://bdl.stat.gov.pl/BDL/start].

Tabela 5. Wyniki estymacji KMNK

\begin{tabular}{|c|c|c|c|c|c|c|}
\hline Sekcja & Wskaźnik & Współczynnik & $\begin{array}{c}\text { Błąd } \\
\text { standardowy }\end{array}$ & $t$-Studenta & Wartość $p$ & $R^{2}$ \\
\hline \multirow{2}{*}{$\begin{array}{l}\text { Górnictwo } \\
\text { i wydobywanie }\end{array}$} & const & 0,80 & 0,02 & 46,28 & $0,00000000682 * * *$ & \multirow[t]{2}{*}{0,545} \\
\hline & bezgorn & 0,09 & 0,03 & 2,68 & $0,0364 * *$ & \\
\hline \multirow{2}{*}{$\begin{array}{l}\text { Przetwórstwo } \\
\text { przemysłowe }\end{array}$} & const & 0,40 & 0,08 & 4,85 & $0,0029 * * *$ & \multirow[t]{2}{*}{0,86} \\
\hline & bezprzet & 0,57 & 0,09 & 6,14 & $0,0009 * * *$ & \\
\hline \multirow{2}{*}{$\begin{array}{l}\text { Wytwarzanie } \\
\text { i zaopatrywanie } \\
\text { w energię } \\
\text { elektryczną }\end{array}$} & const & 0,85 & 0,05 & 16,79 & $0,00000286^{* * *}$ & \multirow[t]{2}{*}{0,003} \\
\hline & bezpwyt & 0,01 & 0,06 & 0,14 & 0,89 & \\
\hline \multirow[t]{2}{*}{ Dostawa wody } & const & 0,63 & 0,20 & 3,07 & $0,022 * *$ & \multirow[t]{2}{*}{0,17} \\
\hline & bezpwoda & 0,27 & 0,24 & 1,11 & 0,31 & \\
\hline
\end{tabular}

Źródło: opracowanie własne na podstawie [https://bdl.stat.gov.pl/BDL/start].

W sekcji „Przetwórstwo przemysłowe” wzrost wskaźnika bezpieczeństwa finansowego o 1 spowoduje wzrost wskaźnika zrównoważonego rozwoju przedsiębiorstw o 0,57 przy współczynniku determinacji równym 86\%. 
Uzyskane wyniki nie pozwalają na jednoznaczne przyjęcie postawionej we wstępie hipotezy badawczej. Przeprowadzone badanie statystyczne wskazało, że przy takiej konstrukcji wskaźników syntetycznych w dwóch z czterech analizowanych sekcji wystąpiła istotna statystycznie zależność. Najwyższy poziom istotności statystycznej ma miejsce w przedsiębiorstwach sekcji „Przetwórstwo przemysłowe”. Najniższy poziom istotności statystycznej dotyczył sekcji „Wytwarzanie i zaopatrywanie w energię elektryczną” oraz „Dostawy wody”. Powodem takiej sytuacji może być fakt, że w znacznym stopniu przedsiębiorstwa $\mathrm{z}$ obu tych sekcji podlegają szczególnym państwowym regulacjom.

\section{Zakończenie}

Zrównoważony rozwój i bezpieczeństwo finansowe przedsiębiorstw należą do kategorii, które są obecnie eksponowane, istotne, a zarazem newralgiczne. Rozwój przedsiębiorstw, który uwzględnia ochronę zasobów przyrody, jest w dobie zmian klimatycznych niezwykle istotny. Zależy on od wielu czynników o charakterze wewnętrznym i zewnętrznym. Jedną z jego podstawowych determinant jest sytuacja finansowo-majątkowa podmiotów gospodarczych. Jednym z jej wyznaczników jest poziom bezpieczeństwa finansowego tych podmiotów. Przeprowadzone badanie pozwoliło ocenić, że w sekcjach „Górnictwo i wydobywanie” (współczynnik korelacji Pearsona 0,74) oraz „Przetwórstwo przemysłowe” (współczynnik korelacji 0,93 ) występuje istotna statystycznie zależność pomiędzy bezpieczeństwem finansowym a zrównoważonym rozwojem przedsiębiorstw. W sekcjach „Wytwarzanie i zaopatrywanie w energię elektryczną” oraz „Dostawa wody” taka zależność nie występuje. Nie można zatem jednoznacznie potwierdzić postawionej we wstępie badania hipotezy badawczej stanowiącej, że bezpieczeństwo finansowe ma istotny statystycznie wpływ na poziom zrównoważonego rozwoju polskich przedsiębiorstw przemysłowych w latach 2010-2017.

\section{Literatura}

Ambec S., Lanoie P., 2008, Does it pay to be green? A systematic overview, Acad. Manage Perspect, no. 22(4), s. 45-62.

Barilenko V.I., 2014, Business analysis as a tool to ensure sustainable development of economic entities, Accounting. Analysis. Audit, no. 1, s. 25-31.

Bednarski L., Waśniewski T. (red.), 1996, Analiza finansowa $w$ zarządzaniu przedsiębiorstwem, t. 1, Fundacja Rozwoju Rachunkowości w Polsce, Warszawa.

Brzozowski T., 2015, Zrównoważony rozwój organizacji- ujęcie praktyczne, Prace Naukowe Uniwersytetu Ekonomicznego we Wrocławiu, nr 377, s. 140.

Burchell J., 2008, The Corporate Social Responsibility Reader, Routledge, Taylor \& Francis Group, London, New York.

Delasa V., Nosova E., Yafinovych O., 2015, Financial security of enterprises, Procedia Economics and Finance, no. 27, s. 250. 
Doane D., MacGillivray A., 2001, Economic Sustainability - The Business of Staying in Business, New Economics Foundation, London, http://www.projectsigma.co.uk/RnDStreams/RD_economic sustain.pdf.

Dresner S., 2002, The Principles of Sustainability, Earthscan, London.

Duraj A.N., 2010, Nadzór korporacyjny a bezpieczeństwo finansowe przedsiębiorstw, [w:] P. Urbanek (red.), Nadzór korporacyjny w warunkach kryzysu gospodarczego, Wydawnictwo Uniwersytetu Łódzkiego, Łódź.

Dyllick T., Hockerts K., 2002, Beyond the case for corporate sustainability, Bus. Strat. Environ., no. 11, s. 131.

Franc-Dąbrowska J., 2006, Bezpieczeństwo finansowe a efektywność zaangażowania kapitałów własnych, Roczniki Nauk Rolniczych, Seria G.

Giovannoni E., Fabietti G., What Is Sustainability? A Review of the Concept and Its Applications, http:// www.pmir.it/fileCaricati/1/Giovannoni\%20and\%20Fabietti\%20(2013).pdf.

Gray R., 2010, Is accounting for sustainability actually accounting for sustainability and how would we know?, An exploration of narratives of organisations and the planet, Account. Org. Soc., no. 35(1), s. 47-62.

Grudzewski W., Hejduk I., Sankowska A., Wańtuchowicz M., 2010, Sustainability w biznesie, Poltex, Warszawa.

Hull C., Rothenberg S., 2008, Firm performance: The interactions of corporate social performance with innovation and industry differentiation, Strateg. Manag., no. 29(7), s. 781-789.

http://swaid.stat.gov.pl.

https://bdl.stat.gov.pl/BDL/start.

Jaffe A., Peterson S., Portney P., Stavins R., 1995, Environmental regulation and the competitiveness of US manufacturing: What does the evidence tell us?, J. Econ. Lit., no. 33(1), s. 132-163.

Karbownik L., 2012, Pojęcie i obszary kreowania oraz zapewnienia bezpieczeństwa finansowego przedsiębiorstwa, Acta Universitatis Lodziensis, Folia Oeconomica, nr 267.

Karbownik L., 2014, Wykorzystanie podejścia memoriałowego i kasowego w ocenie operacyjnego bezpieczeństwa finansowego przedsiębiorstw sektora TSL, Wydawnictwo Uniwersytetu Łódzkiego, Łódź.

Koryakov A.G., 2012 Methodological issues of sustainable enterprise development, Issues of Economics and Law, no. 4, s. 110-114.

Koszel M., Weinert A., 2013, Wykorzystanie koncepcji społecznej odpowiedzialności przedsiębiorstw $i$ zrównoważonego rozwoju $w$ kreowaniu innowacyjnego produktu - studia przypadków, Studia i Prace Wydziału Nauk Ekonomicznych i Zarządzania, Wydawnictwo Uniwersytetu Szczecińskiego, Szczecin.

Maslou A.H., 2003, Motivacija i lichnost', Spb., Piter.

Medvedyeva I.B., Pohosova M.Y., 2011, Diahnostuvannya bezpeky promyslovoho pidpryyemstva u tryrivneviy systemi finansovykhvidnosyn, Vyd. KhNEU, Kharkiv.

Miles M., Covin J., 2000, Environmental marketing: A source of reputational, competitive and financial advantage, J. Bus. Ethic., no. 23(3), s. 299-311.

Misztal A., 2018, Zrównoważony rozwój polskich przedsiębiorstw - ewaluacja, Handel Wewnętrzny, nr 2(373), s. 27-40.

Molina-Azorin J.F., Claver-Cortes E., Lopez-Gamero M.D, Tari J.J., 2009, Green management and financial performance: A literature review, Manag. Decis., no. 47(7), s. 1080-1100.

Nasza wspólna przyszłość, Raport Światowej Komisji do spraw Środowiska i Rozwoju, Państwowe Wydawnictwo Ekonomiczne, Warszawa 1991.

Orlitzky M., Schmidt F.L., Rynes S.L., 2003, Corporate social and financial performance: A metaanalysis, Organ. Stud., nr 24(3), s. 403-441.

Poskrobko B., 1998, Podstawy polityki ekologicznej, [w:] Górka K., Poskrobko B., Radecki W., Ochrona środowiska. Problemy społeczne, ekonomiczne i prawne, PWE, Warszawa. 
Raczkowski K., 2014, Bezpieczeństwo finansowe, [w:] Płaczek J. (red.), Ekonomika bezpieczeństwa państwa w zarysie, Difin, Warszawa.

Sierpińska M., Jachna T., 2004, Ocena przedsiębiorstwa wedlug standardów światowych, Wydawnictwo Naukowe PWN, Warszawa.

Tran Thi Hai Yen, Tran Thi Thanh Thuy, Tereshchenko S., 2018, Modern approaches to the definition of sustainable enterprises development, Higher Education, Skills and Work-Based Learning, no. 8, vol. 4, s. 171.

Trojanowski T., 2015, Przedsiębiorstwa wobec wyzwań zrównoważonego rozwoju, Zeszyty Naukowe Politechniki Śląskiej, Seria: Organizacja i Zarządzanie, z. 77, s. 244.

Witek-Crabb A., 2005, Zrównoważony rozwój przedsiębiorstw - więcej niż ekorozwój, [w:] Brdulak H., Gołębiowski T., Trans'05 Wspólna Europa, Zrównoważony rozwój przedsiębiorstwa a relacje z interesariuszami, Szkoła Główna Handlowa w Warszawie, Warszawa.

Zahorodniy A.H., Voznyuk H.L., 2007, Finansovo-ekonomichnyy slovnyk, K. Znannya. 